\title{
Bacterial microflora of the upper gastrointestinal tract in infants with protracted diarrhoea
}

\author{
D. N. CHALLACOMBE, JUDITH M. RICHARDSON, B. ROWE, and \\ CHARLOTTE M. ANDERSON \\ From the Institute of Child Health, University of Birmingham; and the Salmonella and Shigella Reference \\ Laboratory, Central Public Health Laboratory, Colindale, London
}

\begin{abstract}
Challacombe, D. N., Richardson, J. M., Rowe, B., and Anderson, C. M. (1974). Archives of Disease in Childhood, 49, 270. Bacterial microflora of the upper gastrointestinal tract in infants with protracted diarrhoea. The aerobic and anaerobic bacterial microflora of the upper gastrointestinal tract in infants with protracted diarrhoea has been described and compared with a group of control infants without diarrhoea. The duodenal juice of patients with protracted diarrhoea was rarely sterile and was characterized by an increase in numbers and types of microorganisms and by the presence of coliforms, particularly Esch. coli. In individual patients the same serotypes of Esch. coli were found throughout the intestinal tract. The presence of Esch. coli in the upper small intestine may be as important to the aetiology of protracted diarrhoea as it is to acute diarrhoea.
\end{abstract}

An abnormal bacterial microflora has been reported in the upper small intestine of infants with protracted diarrhoea and carbohydrate intolerance (Gracey, Burke, and Anderson, 1969; CoelloRamirez, Lifshitz, and Zuniga, 1972) and in infants with protracted diarrhoea and carbohydrate intolerance after small intestinal surgery (Burke and Anderson, 1966). In these reports a profuse aerobic microflora was isolated from the small intestine but the anaerobic microflora was not described. A more extensive investigation of the microflora, including the anaerobic organisms, was therefore indicated in patients with protracted diarrhoea. The results of such a study are compared with the bacteriological findings in the previous article in a group of infants without diarrhoeal disorders (Challacombe, Richardson, and Anderson, 1974). These infants will be referred to as the controls.

\section{Patients}

Details of the infants and children studied are shown in Table I. None had received antibiotics for 2 weeks before intubation, nor had salmonellas or shigellas been isolated from these patients.

Group 1. Infants with chronic diarrhoea (7 cases). Chronic diarrhoea in infancy is defined in this investigation as the passage of 4 or more loose, watery stools a day for more than 2 weeks. The infants in this group presented with an acute attack of diarrhoea which did not respond to conventional treatment. They formed a heterogeneous group consisting of 4 infants with chronic nonspecific gastroenteritis, 2 infants with secondary monosaccharide intolerance, and 1 with secondary lactose intolerance.

TABLE I

Details of patients studied

\begin{tabular}{|c|c|c|c|}
\hline No. & Age & Sex & Diagnosis \\
\hline \multicolumn{4}{|c|}{ Group 1: chronic diarrhoea } \\
\hline 1 & $6 \mathrm{wk}$ & $\mathbf{M}$ & Chronic nonspecific gastroenteritis \\
\hline 2 & $6 \mathrm{wk}$ & $\mathbf{F}$ & Secondary monosaccharide intolerance \\
\hline 3 & $2 \mathrm{mth}$ & $\mathrm{F}$ & Chronic nonspecific gastroenteritis \\
\hline 4 & $3 \mathrm{mth}$ & $\mathbf{F}$ & Secondary monosaccharide intolerance \\
\hline 5 & $3 \mathrm{mth}$ & $\mathrm{F}$ & Chronic nonspecific gastroenteritis \\
\hline 6 & $4 \mathrm{mth}$ & $\mathrm{M}$ & Secondary lactose intolerance \\
\hline 7 & $4 \mathrm{mth}$ & $\mathbf{F}$ & Chronic nonspecific gastroenteritis \\
\hline \multicolumn{4}{|c|}{ Group 2: postoperative diarrhoea } \\
\hline 1 & $1 \mathrm{mth}$ & $\mathbf{M}$ & Gastrocolic fistula \\
\hline 2 & $2 \mathrm{mth}$ & $\mathrm{F}$ & Multiple congenital jejunal strictures \\
\hline 3 & $3 \mathrm{mth}$ & $\mathbf{F}$ & Duodenal atresia \\
\hline 4 & $4 \mathrm{mth}$ & $\mathrm{M}$ & Hirschsprung's disease \\
\hline 5 & $1 \mathrm{yr}$ & $\mathrm{F}$ & Hirschsprung's disease \\
\hline 6 & $1 \frac{1}{2}$ yr & $\mathbf{M}$ & Hirschsprung's disease \\
\hline 7 & $5 \mathrm{yr}$ & $\mathbf{M}$ & Hirschsprung's disease \\
\hline \multicolumn{4}{|c|}{ Acute diarrhoea } \\
\hline 1 & 7 mth & $\mathbf{F}$ & Acute gastroenteritis \\
\hline
\end{tabular}




\section{Bacterial microflora of the upper gastrointestinal tract in infants with protracted diarrhoea 271}

Group 2. Postoperative patients (7 cases). This group of infants and children presented with failure to thrive and protracted diarrhoea after partial resections of the large or small intestine.

Acute diarrhoea ( 1 case). One infant with acute Esch. coli gastroenteritis was studied in order to determine the distribution of an accepted enteropathogenic Esch. coli serogroup within the gastrointestinal tract.

\section{Materials and methods}

Sampling technique. A detailed description of the sampling regimen used in this study has been reported in the article preceeding this one (Challacombe et al., 1974). The samples of duodenal juice in all infants studied were taken at 10.00 a.m., approximately 2 hours after a milk feed.

Microbiological methods. Details of the microbiological methods used have also been described in Challacombe et al. (1974). In 5 patients (Table II) 10 lactose-fermenting colonies cultured from the throat, stomach, duodenum, and rectum were selected from each MacConkey plate. These colonies were studied for their ability to produce indole, urease activity, and utilization of citrate (Simmon's). Those isolates having the biochemical reactions of Esch. coli (Cowan and Steel, 1965 ) were serotyped and their somatic $O$, surface $K$, and flagellar $\mathrm{H}$ antigens determined according to the accepted international scheme (Kauffmann, 1966).

\section{Results}

Infants with chronic diarrhoea. Streptococcus viridans and staphylococci were most frequently isolated from the nose swabs, while the throat swabs most frequently grew Neisseria (Fig. 1 and 2). None of the gastric samples were sterile, and in any infant the same types of organisms were isolated from the gastric juice as were found in the nose and throat (Fig. 3). The duodenal juice grew many types of organisms (Fig. 4) and the mean of the total organism count was $7 \cdot 3 \quad \log _{10} / \mathrm{ml}$. Coliforms were cultured from 5 out of 7 samples in
Chronic diarrhoea

Nasal flora

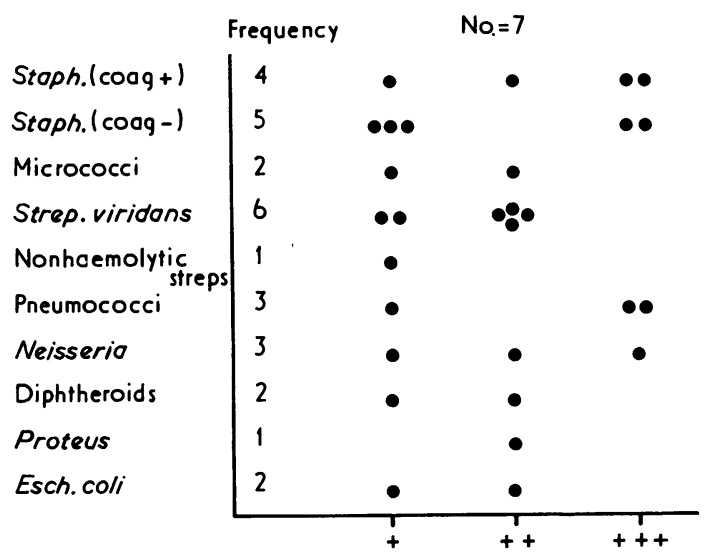

FIG. 1.-Micro-organisms isolated from the noses of 7 patients with chronic diarrhoea.

this group. Bacteroides, an obligate anaerobe, was isolated from 2 infants, 1 with secondary lactose intolerance and 1 with secondary monosaccharide intolerance.

Postoperative infants. The patients in this group had partial resections of either small or large intestine. Few types of organisms were isolated from the nose swabs, but the throat swabs grew similar organisms to those found in infants with chronic diarrhoea (Fig. 5 and 6). One sample of gastric juice was sterile and the organisms isolated from the other 6 samples were similar to those grown from the nose and throat in the same patients (Fig. 7). The duodenal juice was sterile in only 1 patient (Fig. 8), and the mean of the total organism count was $6 \cdot 4 \log _{10} / \mathrm{ml}$. Coliforms were present in 6 out of 7 patients.

TABLE II

Serological Esch. coli typing in 5 patients

\begin{tabular}{|c|c|c|c|c|c|}
\hline $\begin{array}{c}\text { Patients } \\
\text { and diagnoses }\end{array}$ & Chronic diarrhoea & Chronic diarrhoea & $\begin{array}{l}\text { Postoperative } \\
\text { diarrhoea }\end{array}$ & $\begin{array}{c}\text { Postoperative } \\
\text { diarrhoea }\end{array}$ & Acute diarrhoea \\
\hline Throat & & 018ab. H14 & & $\begin{array}{l}\text { 06. H1 } \\
\text { 018ac. H1 }\end{array}$ & \\
\hline Stomach & 021. H2 & 018ab. H14 & & $\begin{array}{l}06 . \mathrm{H} 1 \\
018 \text { ac. H1 }\end{array}$ & \\
\hline Duodenum & $\begin{array}{l}\text { 021. H2 } \\
021 . \mathrm{H}-\end{array}$ & $\begin{array}{l}\text { 018ab. H14 } \\
\text { 018ab. H- }\end{array}$ & 075. H5 & $\begin{array}{l}\text { 06. H1 } \\
\text { 018ac. H1 }\end{array}$ & 0128. H2 \\
\hline Rectum & $\begin{array}{l}\text { 021. H2 } \\
021 . \mathrm{H}-\end{array}$ & 018ab. H14 & $\begin{array}{l}\text { 075. H5 } \\
\text { 06. H31 }\end{array}$ & $\begin{array}{l}\text { 06. H1 } \\
018 \text { ac. H1 }\end{array}$ & 0128. H2 \\
\hline
\end{tabular}




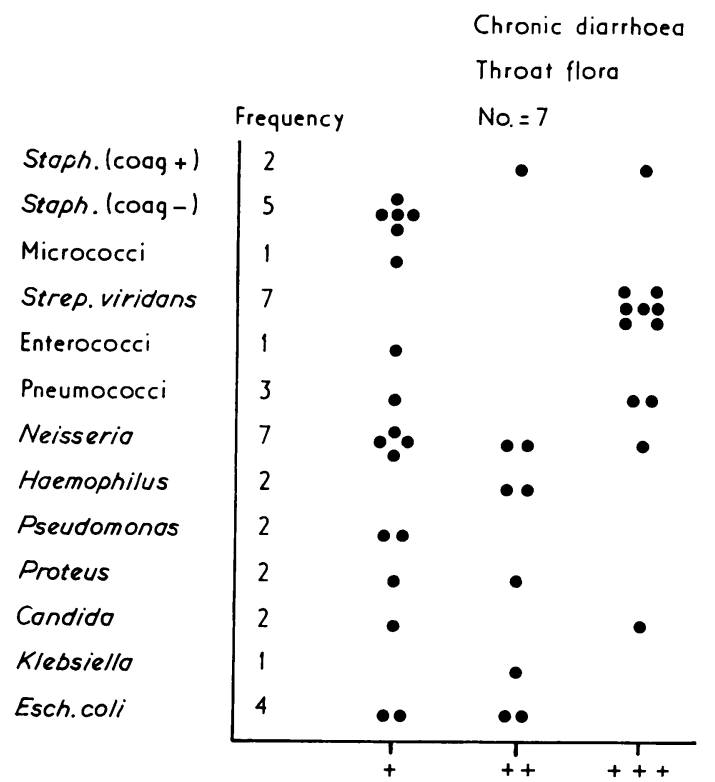

FIG. 2.-Micro-organisms isolated from the throats of 7 patients with chronic diarrhoea.

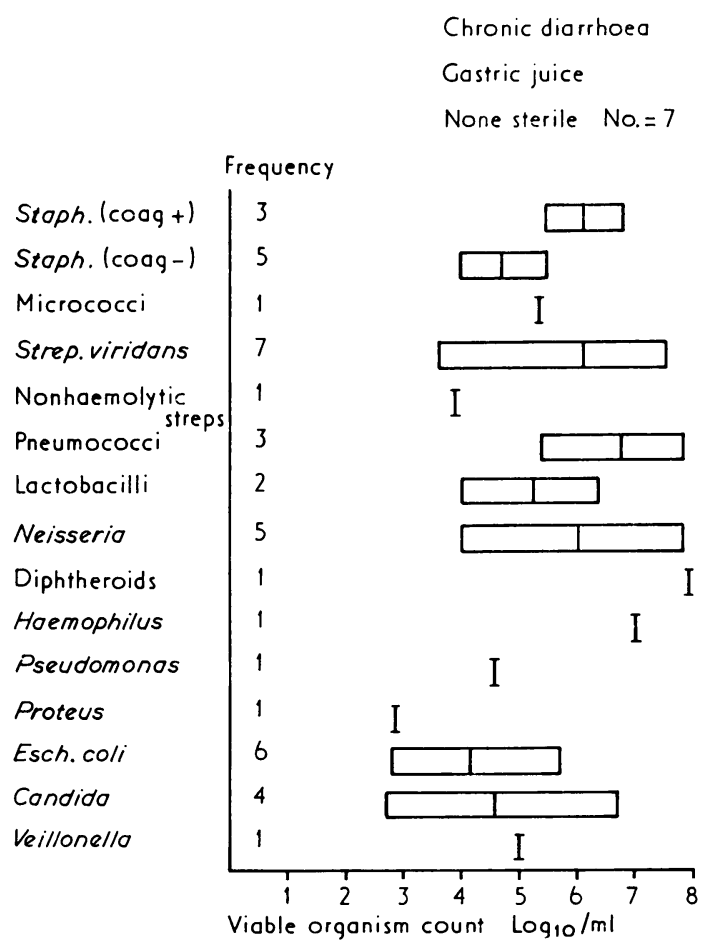

FIG. 3.-Micro-organisms isolated from the gastric juice of 7 patients with chronic diarrhoea.

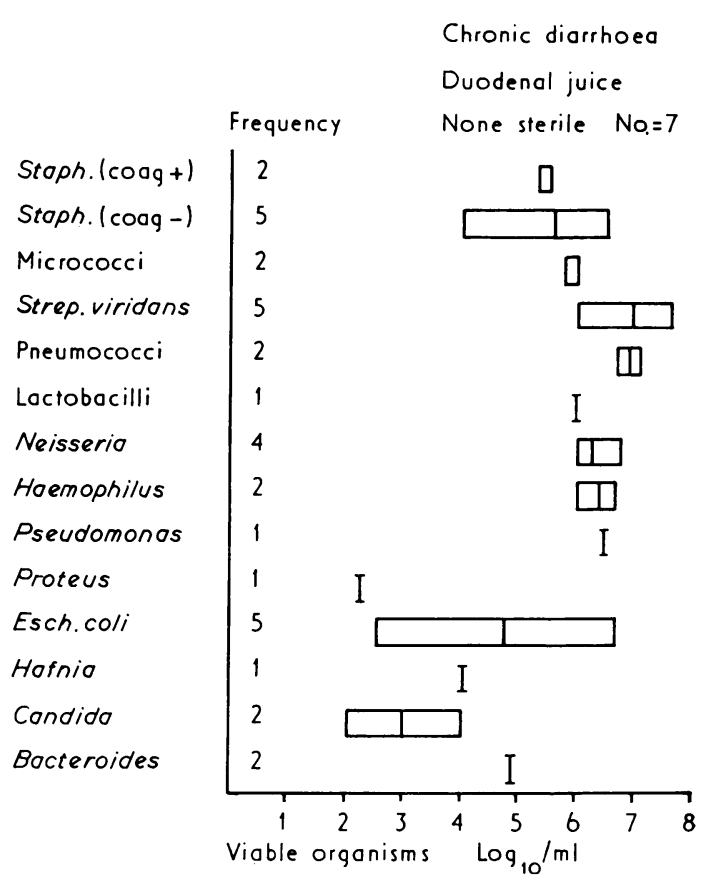

FIG. 4.-Micro-organisms isolated from the duodenal juice of 7 patients with chronic diarrhoea.

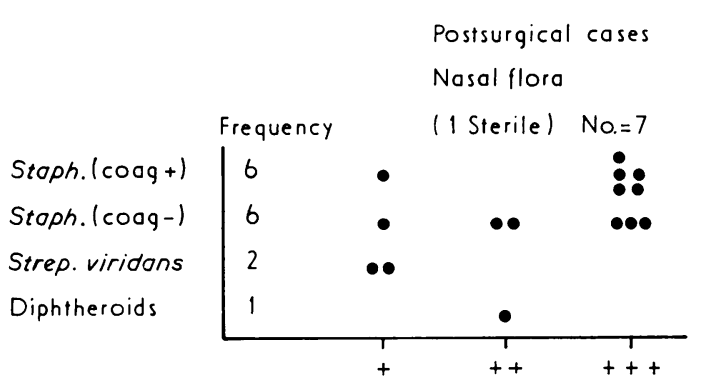

FIG. 5.-Micro-organisms isolated from the noses of 7 patients with diarrhoea after operation.

Comparison of bacteriological results obtained from chronic diarrhoea and postoperative patients with the controls. Only minor qualitative differences were detected in the types of organisms in the nose and throat cultures when comparing the three groups of patients. The gastric juice in each group also grew similar types of organisms with the exception of Candida which was absent from the controls but present in the other two groups. Though coliforms were present in the gastric juice of the controls (6/13), they were more frequently isolated from the chronic diarrhoea $(6 / 7)$ 


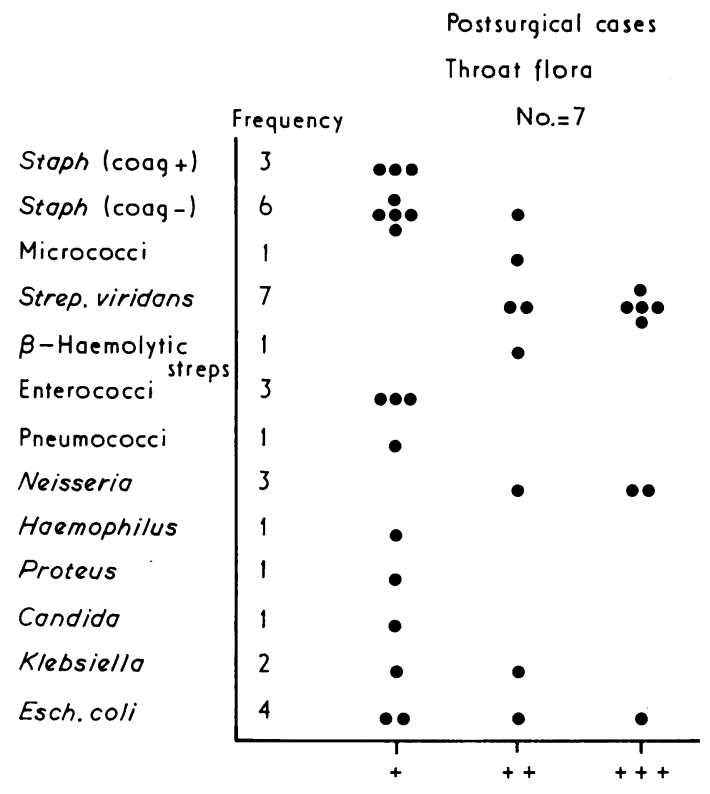

FIG. 6.-Micro-organisms isolated from the throats of 7 patients with diarrhoea after operation.

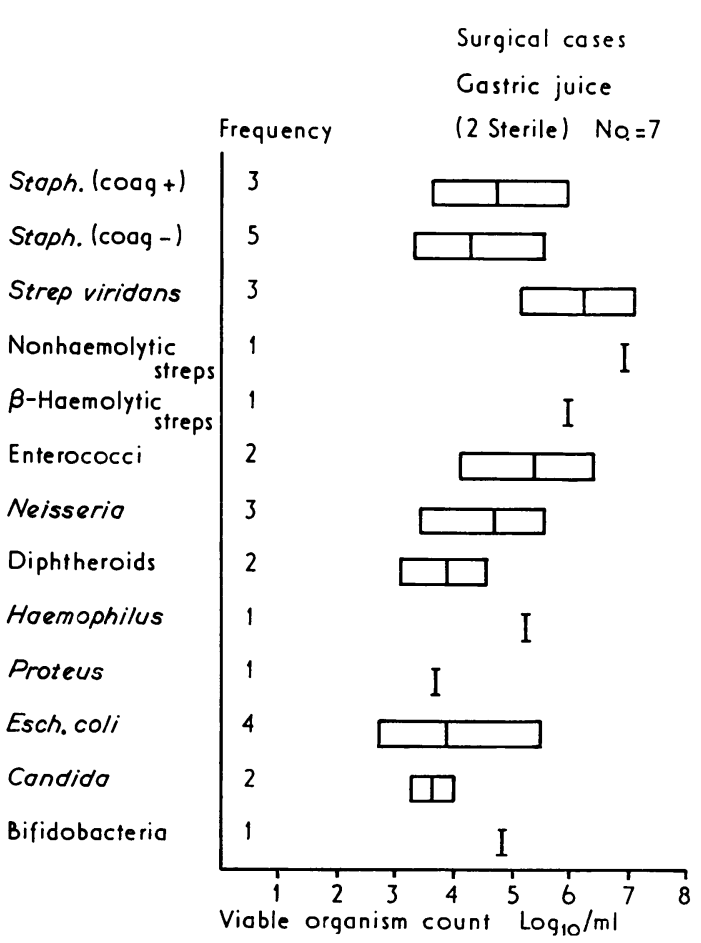

FIG. 7.-Micro-organisms isolated from the gastric juice of 7 patients with diarrhoea after operation.

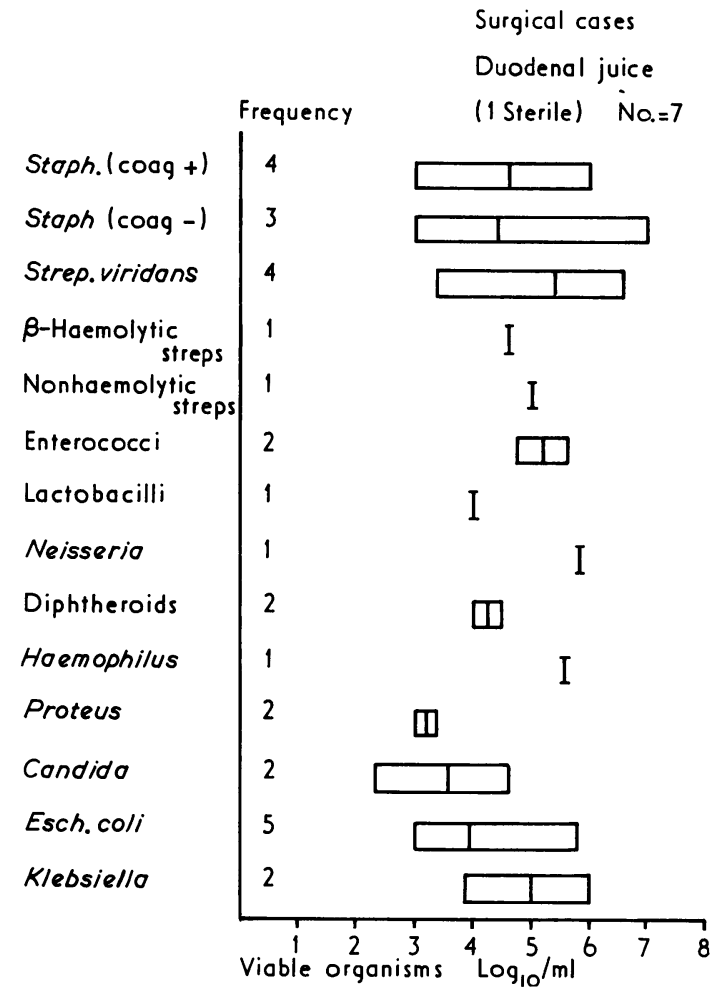

Fig. 8.-Micro-organisms isolated from the duodenal juice of 7 patients with diarrhoea after operation.

and postoperative patients $(4 / 7)$. The mean of the total organism count isolated from the gastric juice in each group is shown in Table III, and shows highest mean values in the chronic diarrhoea patients $\left(7 \cdot 7 \log _{10} / \mathrm{ml}\right)$ and lowest mean values in the postoperative cases $\left(6 \cdot 5 \log _{10} / \mathrm{ml}\right)$.

Major bacteriological differences were shown in the duodenal microflora (Table III). 7 of the 13 control patients had sterile duodenal juice and in the 6 with bacterial growth the organisms did not include Esch. coli or other coliforms. All 13 had bacterial growth in their gastric samples taken shortly beforehand and in 6 of these coliforms were present (5 had Esch. coli). Patients with chronic diarrhoea grew organisms in all 7 duodenal samples, and 5 of these had coliforms (all Esch. coli). Among the postoperative cases only 1 had a sterile duodenal juice and the remaining 6 grew coliforms ( 5 of these had Esch. coli).

A wider range of organisms was isolated from the duodenum of infants with gastrointestinal disorders than from the controls. 14 different types of organisms were identified in both the chronic diarrhoea and postoperative groups, whereas only 8 
TABLE III

Variety and total numbers of organisms $\left(\log _{10} / \mathrm{ml}\right)$ isolated from the gastric juice and first samples of duodenal juice in the chronic diarrhoea and postoperative groups compared with controls

\begin{tabular}{|c|c|c|c|}
\hline & Controls & Chronic diarrhoea & Postoperative \\
\hline $\begin{array}{l}\text { Gastric juice } \\
\text { No. of patients } \\
\text { Sum of total organism count in all infants } \\
\text { Mean of total organism count in all infants } \\
\text { No. of samples sterile } \\
\text { Types of organisms isolated } \\
\text { No. of samples which grew coliforms }\end{array}$ & $\begin{array}{l}13 \\
8 \cdot 4 \log _{10} / \mathrm{ml} \\
7 \cdot 2 \log 10 / \mathrm{ml} \\
1 \\
15 \\
6\end{array}$ & $\begin{array}{l}7 \\
8 \cdot 5 \log _{10} / \mathrm{ml} \\
7 \cdot 7 \log _{10} / \mathrm{ml} \\
0 \\
15 \\
6\end{array}$ & $\begin{array}{l}7 \\
7 \cdot 2 \log _{10} / \mathrm{ml} \\
6 \cdot 5 \log _{10} / \mathrm{ml} \\
2 \\
13 \\
4\end{array}$ \\
\hline $\begin{array}{l}\text { Duodenal juice } \\
\text { Sum of total organism count in all infants } \\
\text { Mean of total organism count in all infants } \\
\text { No. of samples sterile } \\
\text { Types of organisms isolated } \\
\text { No. of samples which grew coliforms }\end{array}$ & $\begin{array}{l}6 \cdot 8 \log _{10} / \mathrm{ml} \\
6 \log _{10} / \mathrm{ml} \\
7 \\
8 \\
0\end{array}$ & $\begin{array}{l}8 \cdot 1 \log _{10} / \mathrm{ml} \\
7 \cdot 3 \log _{10} / \mathrm{ml} \\
0 \\
14 \\
5\end{array}$ & $\begin{array}{l}7 \cdot 2 \log _{10} / \mathrm{ml} \\
6 \cdot 4 \log _{10} / \mathrm{ml} \\
1 \\
14 \\
6\end{array}$ \\
\hline
\end{tabular}

types of organisms were identified in the controls. The mean of the total organism count for each control infant was $6 \log _{10} / \mathrm{ml}$ compared with $6 \cdot 4$ $\log _{10} / \mathrm{ml}$ for each postoperative patient and $7 \cdot 3$ $\log _{10} / \mathrm{ml}$ for each patient with chronic diarrhoea. The viable organism counts in the gastric juice and duodenum of 3 infants with chronic diarrhoea and sugar intolerance, compared with a control infant, are shown in Table IV.

Effect of duodenal $p H$ on the microflora. Increased bacterial growth in the duodenum of children with gastrointestinal disorders has been related to a more alkaline duodenal $p \mathrm{H}$ (Blacklock, Guthrie, and MacPherson, 1937), but this finding has not been confirmed in adults (Gorbach et al., 1967). Duodenal $p \mathrm{H}$ was measured using test papers (Whatman) in the two clinical groups with protracted diarrhoea and compared with the controls (Fig. 9). Using Student's ' $t$ ' test no significant differences were found when comparing one group with any other $(P>0 \cdot 1)$.

Distribution of Esch. coli in gastrointestinal tract of patients with diarrhoea. Special study was made of Esch. coli from various parts of the

TABLE IV

Viable organism count $\left(\log _{10} / \mathrm{ml}\right)$ in 3 patients with chronic diarrhoea and 1 control

\begin{tabular}{|c|c|c|c|c|}
\hline Patients and diagnoses & $\begin{array}{l}\text { Chronic diarrhoea and } \\
\text { secondary lactose } \\
\text { intolerance }\end{array}$ & $\begin{array}{l}\text { Chronic diarrhoea and } \\
\text { secondary monosaccharide } \\
\text { intolerance }\end{array}$ & $\begin{array}{l}\text { Chronic diarrhoea and } \\
\text { secondary monosaccharide } \\
\text { intolerance }\end{array}$ & Control \\
\hline $\begin{array}{l}\text { Gastric juice } \\
\text { Staph. coagulase - } \\
\text { Micrococci } \\
\text { Strep. viridans } \\
\text { Pneumococci } \\
\text { Neisseria } \\
\text { Diphtheroids } \\
\text { Lactobacilli } \\
\text { Esch. coli } \\
\text { Candida albicans } \\
\text { Veillonella }\end{array}$ & $\begin{array}{l}5 \cdot 5 \\
5 \cdot 3 \\
7 \cdot 6 \\
-7 \cdot 8 \\
7 \cdot 8 \\
- \\
6 \cdot 7 \\
-\end{array}$ & $\begin{array}{l}5 \\
6 \cdot 5 \\
5 \cdot 3 \\
5 \cdot 9 \\
\frac{6 \cdot 3}{5 \cdot 8} \\
\frac{5}{-}\end{array}$ & $\begin{array}{l}= \\
= \\
= \\
= \\
3 \cdot 5 \\
2 \cdot 6 \\
-\end{array}$ & $\begin{array}{l}5 \cdot 0 \\
7 \cdot 0 \\
6 \cdot 0 \\
7 \cdot 3 \\
4 \cdot 3 \\
= \\
=\end{array}$ \\
\hline $\begin{array}{l}\text { Duodenal juice } \\
\text { Staph. coagulase - } \\
\text { Micrococci } \\
\text { Strep. viridans } \\
\text { Pneumococci } \\
\text { Neisseria } \\
\text { Haemophilus } \\
\text { Proteus } \\
\text { Esch. coli } \\
\text { Hafnia } \\
\text { Candida albicans } \\
\text { Bacteroides }\end{array}$ & $\begin{array}{l}5 \cdot 8 \\
5 \cdot 9 \\
6 \cdot 9 \\
-6 \cdot 7 \\
6 \cdot 0 \\
= \\
= \\
2 \cdot 0 \\
5 \cdot 0\end{array}$ & $\begin{array}{l}6 \\
6 \\
7 \\
7 \\
6 \\
\overline{-} \\
6 \cdot 3 \\
\overline{4} \\
5 \cdot 0\end{array}$ & $\begin{array}{l}= \\
\bar{Z} \\
\bar{Z} \\
2 \cdot 3 \\
2 \cdot 6 \\
=\end{array}$ & $\begin{array}{l}= \\
= \\
= \\
= \\
\bar{z}\end{array}$ \\
\hline
\end{tabular}




\section{Bacterial microflora of the upper gastrointestinal tract in infants with protracted diarrhoea 275}

$$
\begin{aligned}
& \text { Duodenal juice } \mathrm{pH} \\
& \qquad \begin{array}{l}
\text { Controls } \\
\bar{x}=6.6
\end{array} \stackrel{\text { Chronic diarrhoea }}{\bar{x}=7.25} \quad \bar{x}=7.0
\end{aligned}
$$

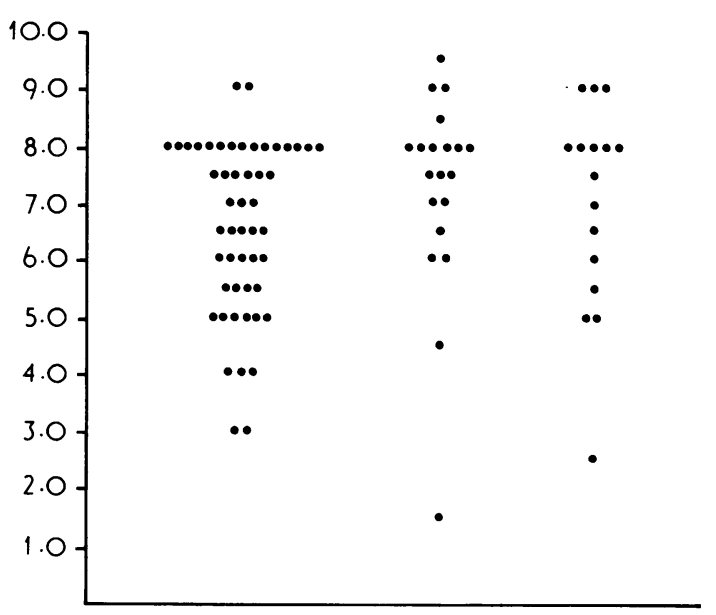

FIG. 9.-Duodenal $\mathrm{pH}$ in controls, in patients with chronic diarrhoea, and in postoperative patients.

gastrointestinal tract in 2 patients with chronic diarrhoea, 2 patients with postoperative diarrhoea, and 1 patient with acute diarrhoea (Table II).

In 2 patients with chronic diarrhoea, the same Esch. coli serotypes (021. H2 and 018ab. H14, respectively) were present throughout the intestinal tract, occurring in gastric juice, duodenal juice, and rectum. Another serotype, 021. $\mathrm{H}-$, was isolated from the duodenum and rectum in the first patient and $018 \mathrm{ab}$. $\mathrm{H}$-, was isolated from the duodenum of the second patient. In one postoperative patient, Esch. coli 075. H5 was present in the duodenal juice and the rectum, and $06 . \mathrm{H} 31$ was isolated from the rectum. In the other, Esch. coli 018ac. H1 and Esch. coli 06 . H1 were found in the throat, stomach, duodenum, and rectum.

The patient with acute diarrhoea grew Esch. coli 0128 in the duodenum and rectum. This is an accepted enteropathogenic serogroup.

\section{Discussion}

In this investigation the upper gastrointestinal microflora has been defined in two groups of infants with protracted diarrhoea and the results have been compared with a group of control infants. Major bacteriological differences between the three groups studied were only shown in the duodenum.
The results show that the duodenum in control infants is often sterile, and that any organisms present probably result from the passage of food and gastric juice through the duodenum. Other workers (Kalser et al., 1966) defined an upper numerical limit to the total bacterial count in the duodenum of normal adults of $3.0 \log _{10} / \mathrm{ml}$ above which the total count becomes abnormal. We were unable to confirm this finding in the 6 control infants from whom duodenal bacteria were isolated, and the total count in these infants ranged from 3.0-6.0 $\log _{10} / \mathrm{ml}$. The duodenum of infants with protracted diarrhoea was rarely sterile. These patients also differed from the controls by an increase in the mean of the total organism count for each patient and an increase in the number of types of organisms isolated. Nonenteropathogenic Esch. coli serotypes were also frequently isolated from the duodenum of patients with protracted diarrhoea. These organisms were not isolated from the duodenum of the controls even though they were present in 6 out of 13 samples of gastric juice aspirated one hour beforehand. In a detailed study of Esch. coli in 4 patients with protracted diarrhoea the serotypes isolated from the rectal swabs were also found in the upper gastrointestinal tract. Similar findings were shown in a patient with acute gastroenteritis due to an enteropathogenic serotype, confirming one previous report (Thomson, 1955).

The results of this investigation have not established whether bacterial overgrowth in the upper small intestine causes protracted diarrhoea or whether this is a nonspecific finding secondary to disordered small intestinal function. As the duodenum in control infants was often sterile, our results suggest that small intestinal mechanisms which limit bacterial growth may be impaired in patients with protracted diarrhoea. These mechanisms have been studied in experimental animals and the importance of intestinal peristalsis in clearing organisms from the small intestine has been shown (Dack and Petran, 1934; Dixon 1960).

As small intestinal stasis and delayed intestinal transit have been reported in infants with acute diarrhoea (Rodriguez-de-Curet, Lugo-de-Rivera, and Torres-Pinedo, 1970) and in infants with diarrhoea and malnutrition (Dammin, 1965), impaired peristalsis could be one explanation for our bacteriological findings. It is also possible to speculate that the production of an 'antiperistalsis factor' by organisms in the small intestine could cause intestinal stasis, resulting in persistent bacterial overgrowth and protracted diarrhoea.

A luxuriant small intestinal microflora has been reported in adults with intestinal stasis resulting 
from blind loops of small intestine (Goldstein, Wirts, and Josephs, 1962). The commonest jejunal organism originally isolated from these patients was Esch. coli (Dellipiani and Girdwood, 1964; Donaldson, 1967). However, recent advances in anaerobic culture techniques (Drasar, 1967) have shown that Bacteroides and anaerobic lactobacilli are also commonly present in the jejunum of these patients in concentrations of $3 \cdot 0-8 \cdot 0 \quad \log _{10} / \mathrm{ml}$ (Drasar, Hill, and Shiner, 1966). Small intestinal stasis in the duodenum of 2 patients with chronic diarrhoea is also suggested by the finding of similar concentrations of Bacteroides ( $5 \log _{10} / \mathrm{ml}$ ).

The finding that Esch. coli serotypes may colonize different parts of the gastrointestinal tract in patients with protracted diarrhoea suggests that factors unrelated to impaired peristalsis could also contribute to the presence of these organisms in the duodenum. In piglet enteritis, an important factor in the establishment of the enteropathogenic Esch. coli is the presence of a particular antigen ( $\mathrm{K} 88)$, which appears to enhance the ability of this organism to adhere to the intestinal mucosa (Smith and Lingood, 1971). Further investigations are needed to assess the possible importance of a similar mechanism in Esch. coli causing human enteritis.

An abnormally profuse duodenal microflora associated with carbohydrate intolerance has been reported in patients with protracted diarrhoea after small intestinal surgery (Burke and Anderson, 1966) and in infants with protracted diarrhoea not previously subjected to operation (Gracey et al., 1969; Coello-Ramirez et al., 1972). The abnormality of the upper small intestinal microflora in these reports paralleled the severity of carbohydrate intolerance, and the total bacterial count decreased with improving carbohydrate tolerance and recovery from the diarrhoea. A total bacterial count in the upper small intestine of $4 \cdot 0-5 \cdot 0$ $\log _{10} / \mathrm{ml}$ was reported in infants with specific lactose intolerance, while infants with secondary monosaccharide intolerance had a total count of $8 \log _{10} / \mathrm{ml}$ (Coello-Ramirez et al., 1972). Coliforms were the organisms most frequently isolated from these patients. Total counts of duodenal bacteria in 2 of our patients with chronic diarrhoea and secondary monosaccharide intolerance were $2.7 \log _{10} / \mathrm{ml}$ and $7.0 \log _{10} / \mathrm{ml}$, and nonenteropathogenic Esch. coli serotypes were found in concentrations of 2.6 $\log _{10} / \mathrm{ml}$ and $6.3 \log _{10} / \mathrm{ml}$, respectively. In the second of these infants, Bacteroides $\left(5 \log _{10} / \mathrm{ml}\right)$ were also isolated. The total duodenal bacterial count in 1 patient with chronic diarrhoea and secondary lactose intolerance was $7 \log _{10} / \mathrm{ml}$. These results do not show a direct relation between the total bacterial count and specific types of sugar intolerance, as has been suggested (Coello-Ramirez et al., 1972), and total duodenal bacterial counts from $4 \cdot 0 \log _{10} / \mathrm{ml}$ to $7.0 \log _{10} / \mathrm{ml}$ were also found in 4 patients with chronic diarrhoea who tolerated dietary sugars normally.

Chronic diarrhoea associated with impaired carbohydrate intolerance is usually secondary to an acute attack of gastroenteritis. The organism causing the acute illness, such as an enteropathogenic Esch. coli, may also be responsible for impaired carbohydrate digestion and absorption, by damaging the small intestinal epithelium and lowering its enzymatic content. In these circumstances the presence of unabsorbed sugar in the upper small intestine may encourage the growth of an abnormal microflora.

Coliforms were isolated from the small intestine of 3 infants who had protracted diarrhoea and were failing to thrive after partial resection of the small intestine. These organisms were also present in the duodenum of 3 older children who had developed protracted diarrhoea after partial large intestinal resection for Hirschsprung's disease. Colonization of the small intestine with coliforms can therefore occur in infants with protracted diarrhoea after operation on either the small or large intestine.

Acute diarrhoea in older children and adults may be due to a bacterial pathogen such as Salmonella or Shigella, and the accepted infantile enteropathogenic Esch. coli have been shown in individual cases and outbreaks (Schroeder et al., 1968). Nevertheless, in a high percentage of cases no bacterial pathogen is found (Gorbach et al., 1971). Sakazaki, Tamura, and Saito (1967) reported that in Japan acute diarrhoea in older children and adults might be associated with different $\mathrm{O}$ groups to those which are traditionally regarded as causing infantile diarrhoea. Rowe, Taylor, and Bettelheim (1970), in a study of diarrhoea in British troops recently arrived in Arabia, showed that a serotype of a new and previously unrecognized Esch. coli $\mathrm{O}$ group was responsible for a high proportion of cases, and Dupont et al. (1971) have shown that this serotype produced an enterotoxin which dilated the rabbit gut loop.

It is essential to be aware that diarrhoea may be caused by Esch. coli serotypes belonging to $O$ groups other than those commonly regarded as enteropathogenic. Gorbach et al. (1971) studied Esch. coli isolated from the duodenum of cases of acute diarrhoea in Calcutta. Most of these Esch. coli serotypes would be commonly regarded as nonenteropathogenic, but nevertheless some of these organisms produced an enterotoxin which gave a 


\section{Bacterial microflora of the upper gastrointestinal tract in infants with protracted diarrhoea 277}

positive reaction to the rabbit intestinal loop. The presence of Esch. coli in the duodenum may be as important to the aetiology of protracted diarrhoea as it is to acute diarrhoea. Accurate serotyping of Esch. coli is necessary in these patients, but so also is the examination of such isolates for enterotoxin production. The relation of enterotoxin production to serotype will need to be evaluated carefully in the future.

We are grateful to Dr. K. B. Rogers, Mr. G. A. Brown, and the consultants and nursing staff of the Birmingham Children's Hospital and East Birmingham Hospital for help and advice with this investigation. D.N.C. was supported by a grant from the Endowment Fund of the United Birmingham Hospitals and J.R. by a grant from the Medical Research Council.

\section{REFERENCES}

Blacklock, J. W. S., Guthrie, K. J., and MacPherson, I. (1937). A study of the intestinal flora of children. Fournal of Pathology and Bacteriology, 44, 321.

Burke, V., and Anderson, C. M. (1966). Sugar intolerance as a cause of protracted diarrhoea following surgery of the gastrointestinal tract in neonates. Australian Paediatric fournal, 2, 219.

Challacombe, D. N., Richardson, J. M., and Anderson, C. M. (1974). Bacterial microflora of upper gastrointestinal tract in infants without diarrhoea. Archives of Disease in Childhood, 49, 264.

Coello-Ramirez, P., Lifshitz, F., and Zuniga, V. (1972). Enteric microflora and carbohydrate intolerance in infants with diarrhea. Pediatrics, 49, 233.

Cowan, S. T., and Steel, K. J. (1965). Manual for the Identification of Medical Bacteria. Cambridge University Press, London.

Dack, G. M., and Petran, E. (1934). Bacterial activity in different levels of the intestine and in isolated segments of small and large bowel in monkeys and in dogs. Fournal of Infectious Diseases, 54, 204.

Dammin, G. J. (1965). Pathogenesis of acute clinical diarrheal disease. Federal Proceedings, 24, 35.

Dellipiani, A. W., and Girdwood, R. H. (1964). Bacterial changes in the small intestine in malabsorptive states and in pernicious anaemia. Clinical Science, 26, 359.

Dixon, J. M. S. (1960). The fate of bacteria in the small intestine. fournal of Pathology and Bacteriology, 79, 131.
Donaldson, R. M., Jr. (1967). Role of enteric micro-organisms in malabsorption. Federal Proceedings, 26, 1426.

Drasar, B. S. (1967). Cultivation of anaerobic intestinal bacteria. Fournal of Pathology and Bacteriology, 94, 417.

Drasar, B. S., Hill, M. J., and Shiner, M. (1966). The deconjugation of bile salts by human intestinal bacteria. Lancet, 1, 1237.

Dupont, H. L., Formal, S. B., Hornick, R. B., Snyder, M. J., Libonati, J. P., Sheahan, D. G., LaBrec, E. H., and Kalas, J. P. (1971). Pathogenesis of Escherichia coli diarrhea. New England fournal of Medicine, 285, 1.

Goldstein, F., Wirts, C. W., and Josephs, L. (1962). The bacterial flora of the small intestine. (Abst.) Gastroenterology, 42, 755.

Gorbach, S. L., Banwell, J. G., Chatterjee, B. D., Jacobs, B., and Sack, R. B. (1971). Acute undifferentiated human diarrhea in the tropics. I. Alterations in intestinal microflora. Fournal of Clinical Investigation, 50, 881 .

Gorbach, S. L., Plaut, A. G., Nahas, L., Weinstein, L., Spanknebel, G., and Levitan, R. (1967). Studies of intestinal microflora. II. Micro-organisms of the small intestine and their relations to oral and fecal flora. Gastroenterology, 53, 856.

Gracey, M., Burke, V., and Anderson, C. M. (1969). Association of monosaccharide malabsorption with abnormal small-intestinal flora. Lancet, 2, 384.

Kalser, M. H., Cohen, R., Arteaga, I., Yawn, E., Mayoral, L., Hoffert, W. R., and Frazier, D. (1966). Normal bacterial flora of the human small and large intestine. New England Fournal of Medicine, 274, 500.

Kauffmann, F. (1966). The Bacteriology of Enterobacteriaceae. Munksgaard, Copenhagen.

Rodriguez-de-Curet, H., Lugo-de-Rivera, C., and Torres-Pinedo, R. (1970). Studies on infant diarrhea. IV. Sugar transit and absorption in small intestine after a feeding. Gastroenterology, $59,396$.

Rowe, B., Taylor, J., and Bettelheim, K. A. (1970). An investigation of travellers' diarrhoea. Lancet, $1,1$.

Sakazaki, R., Tamura, K., and Saito, M. (1967). Enteropathogenic Escherichia coli associated with diarrhoea in children and adults. fapanese Fournal of Medical Science and Biology, 20, 387.

Schroeder, S. A., Caldwell, J. R., Vernon, T. M., White, P. C., Granger, S. I., and Bennett, J. V. (1968). A waterborne outbreak of gastroenteritis in adults associated with Escherichia coli. Lancet, $1,737$.

Smith, H. W., and Lingood, M. A. (1971). Observations on the pathogenic properties of the K88, HLY and Ent plasmids of Escherichia coli with particular reference to porcine diarrhoea. fournal of Medical Microbiology, 4, 467.

Thomson, S. (1955). The role of certain varieties of Bacterium coli in gastroenteritis of babies. Fournal of Hygiene, 53, 357.

Correspondence to Dr. D. N. Challacombe, Taunton and Somerset Hospital, Musgrove Park, Taunton, Somerset TA1 5DA. 